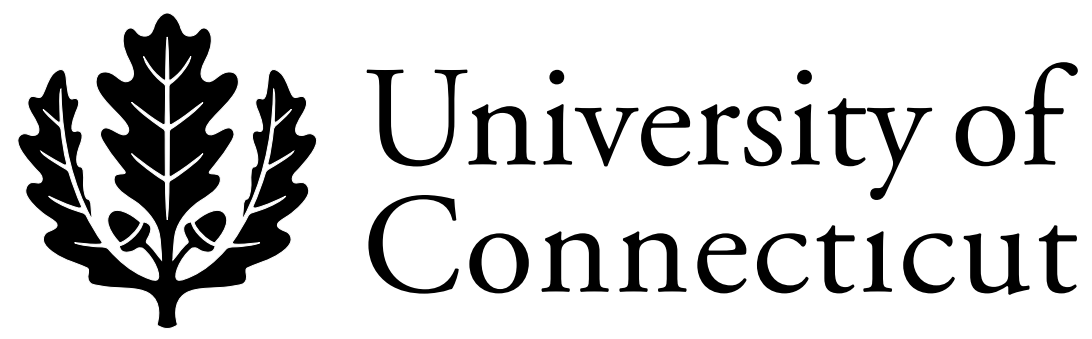

Department of Economics Working Paper Series

\title{
The Improving Relative Status of Black Men
}

Kenneth A. Couch

University of Connecticut

Mary C. Daly

Federal Reserve Bank of San Francisco

Working Paper 2004-12

June 2004

341 Mansfield Road, Unit 1063

Storrs, CT 06269-1063

Phone: (860) 486-3022

Fax: (860) 486-4463

http://www.econ.uconn.edu/ 


\begin{abstract}
Using data from the Current Population Survey, we examine recent trends in the relative economic status of black men. Our findings point to gains in the relative wages of black men (compared to whites) during the 1990s, especially among younger workers. In 1989, the average black male worker (experienced or not) earned about 69 percent as much per week as the average white male worker. In 2001, the average younger black worker was earning about 86as much as an equally experienced white male; black males at all experience levels earned 72 percent as much as the average white in 2001. Greater occupational diversity and a reduction in unobserved skill differences and/or labor market discrimination explain much of the trend. For both younger and older workers, general wage inequality tempered the rate of wage convergence between blacks and whites during the 1990s, although the effects were less pronounced than during the 1980s.
\end{abstract}

Journal of Economic Literature Classification: J15, J31

We thank Frederick Furlong for helpful comments and Anita Todd for editorial assistance. The views expressed in this paper are those of the authors and do not necessarily reflect the views of the Federal Reserve Bank of San Francisco or the Federal Reserve System. 


\section{The Improving Relative Status of Black Men}

\section{Introduction}

Prior to 1990, the evolution of black male wages relative to white male wages could be divided into two distinct periods: (1) 1964 through 1974, when the weekly differential in blackwhite wages fell precipitously; and (2) 1975 through 1989, when the differential remained relatively constant and even rose somewhat. Evidence for the 1990s and the early part of this century indicate that a third period has emerged, with black males again gaining ground relative to whites. Between 1990 and 2001, the weekly wage differential between black and white males fell at an average annual rate of 0.6 percent per year. Wage convergence among men with less than 10 years of experience was even more rapid, averaging 1.4 percent per year. ${ }^{1}$ While these gains fall short of the pace of decline recorded from 1964 to 1974, they represent a return to a pattern of relative improvement after a long period of stasis.

This recent improvement in the relative status of black men raises questions about the factors driving the change. Past research on the early declines and the subsequent stagnation in black-white wage gaps point to a number of important factors including differences in productivity (observable and unobservable) and employment structure, as well as changes in economy-wide male wage inequality and discrimination (see Altonji and Blank (1999) for a detailed review of this literature). Despite considerable efforts, little consensus has formed about the primary determinants of these trends.

\footnotetext{
${ }^{1}$ The figures cited in this paragraph are based on calculations presented and explained later in the text. 
We contribute to the literature in this area by documenting recent changes in the blackwhite wage gap and examining the factors contributing to the recent improvement. We begin by reviewing the literature on black-white wage gaps, paying particular attention to research focused on disentangling the effects of changes in skill, changes in discrimination, and changes in economy-wide wage inequality. We then use data from the March Current Population Survey (CPS) to document trends in the weekly differential of black-white wages from 1968 to 2001. Using standard decomposition techniques, we examine the relative importance of productivity differences, the employment structure, economy-wide male wage inequality, and discrimination in explaining the time-series pattern of the black-white wage ratio.

We find that greater occupational diversity and reductions in unobserved or residual differences were important to reducing the gap during the 1990s. General male wage inequality continued to temper the rate of wage convergence between blacks and whites. The results raise the possibility that the 15 year stasis between 1975 and 1989 was episodic, rather than indicative of a more permanent state.

\section{Identifying the Issues}

Considerable research has focused on understanding changes in black economic status since 1960. Initial studies focused on separating black economic advancement into the portion associated with changes in skill including educational attainment and the portion associated with governmental efforts to combat discrimination, including antidiscrimination policies and affirmative action. $^{2}$ The key determinants of these apportionments were the relative progress of

\footnotetext{
${ }^{2}$ Title VII of the 1964 Civil Rights Act forbid discrimination in employment. The Office of Federal Contract Compliance, established in 1964, monitors the anitidiscrimination and affirmative action responsibilities of government contractors. The Voting Rights Act of 1965 extended protections
} 
older versus newer cohorts and the timing of the progress relative to the onset of government antidiscrimination policies. The results produced no clear consensus. Smith and Welch (1977, 1984, 1989), finding that the replacement of older cohorts by newer cohorts was driving the improvement in relative wages among blacks, concluded that skill convergence, rather than antidiscrimination policies, were responsible for black economic advancement. Brown (1982), Leonard (1990), Heckman (1989), and Heckman and Payner (1989), showing that in periods of intense government intervention all cohorts advanced, concluded that government policies (e.g., the 1964 Civil Rights Act) played a significant role in the convergence of black and white male wages (see Donohue and Heckman (1991) for a summary of this debate). ${ }^{3}$

As the rate of convergence in the black-white wage gap slowed, attention turned to understanding the factors holding down black wages. Several papers attributed the slowdown to political changes that reduced support (social and financial) for affirmative action (Jaynes 1990; Leonard 1990; Bound and Freeman 1992). Others looked to the economy (Welch 2003) or to the quality of black education (Card and Krueger 1992). Juhn, Murphy, and Pierce (1991) took a different approach and examined the role of economy-wide increases in wage dispersion; they concluded that rising male wage inequality was an important restraint on the advancement of black males relative to whites.

Recent summaries of relative black progress since 1960 by Heckman, Lyons, and Todd (2000) and Welch (2003) suggest that considerable differences of opinion about the importance

from discrimination to black voters.

${ }^{3}$ Several of these studies note that economic conditions also play a role. The booming economy during the period from 1960 to 1970 likely had a positive influence on the improvement of black wages. 
of any particular factor remain. What does seem to be agreed upon is that analysis of trends in the black-white wage gap must recognize the importance of observable and unobservable skills, changes in returns to those skills, changes in economy-wide wage inequality, and changes in discrimination against black workers. That said, we turn to our analysis, which documents recent trends in relative black advancement and the factors contributing to them.

\section{Data}

We use data from the March Current Population Survey (CPS) for the years 1969-2002, as administered by the U.S. Census Bureau for the U.S. Bureau of Labor Statistics. These files provide information on earnings, hours, and related variables for the calendar year prior to the survey date; thus, our analyses apply to income years 1968-2001. In the formal decomposition analysis, we focus on three periods: 1968-1979, 1979-1989, and 1989-2001. These years span our sample and generally coincide with three business cycles. ${ }^{4}$

Our sample consists of black and white males ages 18-64 who participated in the labor force at least 39 weeks, worked at least one week during the year, and usually worked full-time. Workers who are enrolled in school are excluded from the analysis. Throughout the analysis we focus on two groups: our full sample and men with less than ten years of potential experience, (i.e., $\min \left[\right.$ age-education-6, age-18]). ${ }^{5}$

\footnotetext{
${ }^{4}$ The official peak of the 1990s expansion was March 2001, so the last year of our sample includes nine months of a national recession. Excluding the data for 2001 does not materially affect our results.

${ }^{5}$ Recent entrants to the labor market arguably are more reflective of current market conditions as they are not hindered by past discrimination or segregation nor helped by their seniority or specific human capital.
} 
Our empirical analysis focuses on weekly earnings, calculated as the ratio of annual earnings to weeks worked during the year. Weekly earnings are deflated using the personal consumption expenditure deflator from the National Income and Product Accounts. To avoid problems associated with changes in CPS top-coding procedures over the years, our sample excludes individuals in the top and bottom $1 \%$ of the weekly earnings distribution. Throughout the paper, we refer to the log of deflated average weekly earnings as the wage. All analyses are weighted using the survey weights provided in the CPS.

\section{Trends in the Black-White Wage Differential}

\section{Basic Patterns}

The up, down, up progress of black relative wages over the past three decades is displayed in Figure 1. The figure shows trends in black-white weekly wage differentials (unadjusted for differences in measured characteristics) between 1968 and 2001 for all workers and workers with ten or fewer years of potential experience. Like previous researchers, we find that among workers at all experience levels, the gap in the earnings of blacks and whites decreased sharply from the late 1960s through the mid-1970s, falling from 0.50 in 1968 to 0.30 in 1976. Similarly, we find little wage convergence between blacks and whites from the mid1970s through the end of the 1980s (the period examined most recently by other researchers). During this period the wage gap between black and white males averaged 0.33 , rising to 0.37 in 1985 and never falling below 0.31. Since the end of the recession in 1991, however, there have been six observations of the unadjusted wage gap less than $0.30(0.27$ in $1995 ; 0.29$ in $1997 ; 0.27$ in 1998; 0.29 in 1999; 0.26 in 2000; and 0.27 in 2001). These are the smallest weekly wage differentials recorded for black and white males in our sample. Although these are modest 
reductions for minority workers as a whole, they represent progress in wage convergence following nearly two decades of stagnation.

A similar pattern is observed for the subset of workers with less than ten years of potential experience. Again, following fairly rapid narrowing of the black-white wage gap from the late 1960s through the mid-1970s, the pattern reversed during the 1980s, when the gap in weekly wages actually increased. In contrast, during the 1990s, the wages of younger black workers rose relative to their white counterparts. Following the recession in 1991, there were six instances of historical lows for the weekly wage gap among workers with less than ten years of experience $(0.21$ in $1994 ; 0.12$ in $1997 ; 0.18$ in $1998 ; 0.22$ in $1999 ; 0.18$ in 2000 ; and 0.15 in 2001).

\section{Wage Gaps and Potential Experience}

As Figure 1 shows, while both all men and those with less than ten years of potential experience made gains in the 1990s, the improvement was largest for younger men. To highlight these differences more completely, Table 1 provides a detailed breakdown of the evolution of the black-white wage gap by years of potential labor market experience. The wage gaps reported in the table represent averages over five-year intervals of the CPS data.

Looking across the rows of Table 1 shows a marked decline in the unadjusted black-white wage gap among workers of all skill levels (row percent changes reported in final column of talbe). For workers at all levels of experience, the unadjusted wage gap declined from 0.44 in the interval from 1968 through 1972 to 0.27 in the period from 1998 to 2001 , a decrease of 38 percent. For the different levels of potential experience listed in the table, the reductions in the wage gap range from 25 percent (workers with 26-30 years of potential experience) to 53 percent 
(workers with six to ten years of potential experience). The results show that although the relative economic position of all black males has improved over time, newer entrants to the labor market have fared the best.

Turning to the diagonals of the table, we compare the movement of different groups of men (measured by potential experience) over time. ${ }^{6}$ For example, in 1968-72, workers with less than six years of potential experience had an average wage gap of 0.36 ; by 1998-2001, when these men had acquired between 31 and 35 years of potential experience, their wage gap had fallen to 0.32 , a decline of 11 percent. The most pronounced declines were for men who had between six and ten years of potential experience in 1968-1972; these men saw their wage gap fall from 0.40 in the first period of our data to 0.25 percent in the last period of our data, a 38 percent decline. Thus, although newer entrants to the labor market fare better than more established workers, the results point to an overall pattern of convergence independent of age and experience.

\section{Trends in Underlying Wage Determinants}

As noted earlier, several factors have been shown to influence the evolution of the blackwhite wage gap. In this section, we document changes in individual characteristics, the sectoral composition of employment, and overall wage inequality.

\section{Education and Occupation}

${ }^{6}$ Potential experience is not equivalent to cohort analysis, which is another standard way of measuring differential progress of younger and older black males. We rely on potential experience in our analysis for comparability with Juhn, Murphy, and Pierce (1991). 
Basic Trends. Before describing changes in black educational attainment and occupation distribution, it is useful to see why such variables matter for wages. ${ }^{7}$ Beginning with the relationship between education and wages, Figure 2 shows trends in the college-high-school earnings differential for all male workers and those with fewer than ten years potential experience. As the figure indicates, there is a sizeable gap between the wages of college educated and high-school educated men. Moreover, the premium on education has grown dramatically over the past two decades, essentially doubling over the period. By 2001 the wage gap between college and high-school educated men had risen to 65 percent (70 percent for men with fewer than 10 years potential experience). The increasing importance of education for wage determination suggests that changes in educational attainment by race could explain trends in the black white wage gap.

Another important factor for wages is occupation. Figure 3 shows average weekly earnings in 2001 for major occupational groups. The figure reveals a sizeable wage premium for workers in managerial and professional occupations, relative to workers in clerical, craftsman, and laborer occupations. In 2001, workers in the managerial and professional occupations earned two and one half times the wages earned by laborers. Analysis not shown here reveals little change in the relative wages by occupation over time. Thus, the 2001 data can be taken as an accurate summary of the distribution of wages across major occupational categories.

Changes for Blacks. As Figure 2 showed, one of the most important individual determinants of wages is education. It also is an area where blacks have made enormous gains,

${ }^{7}$ Another potential factor affecting black-white wage gaps is industry distribution. Our analysis reveals little difference in the trends in industry distribution between black and whites. Thus, we focus on occupational distribution, which has changed significantly during our sample period. 
both absolutely and relative to whites, over the past 30 years (Table 2). In 1968, 63 percent of black males had not completed high school, nearly twice the percentage for whites. By the last year of our sample, 2001, the percentage of blacks without a high-school education had fallen to $12 \%$, about 1.1 times the percentage for whites. The same pattern of improvement for black males is observed for all levels of educational attainment. By 2001, about 41.9 percent of blacks received a high school degree, 28.2 percent had some college, and about 18 percent had college degrees. This represents considerable improvement over 1968 when 25.6 percent had high school degrees, just 7.4 percent had some college, and only 3.8 percent had college degrees. Still, even with these improvements, blacks lag whites in the in the acquisition of education. ${ }^{8}$ Finally, overall the patterns are similar for blacks with less than ten years of experience (panel B, Table 2), although the distribution of black men is far more evenly weighted across educational groups.

The remainder of Table 2 shows the relative distribution of blacks and whites across 1digit occupational categories. While occupational and industry outcomes potentially reflect both choices and constraints, here we simply display the patterns over time without making a judgement about this issue. As with education we find significant convergence in the occupational distributions of blacks relative to whites over the past 30 years. In 1968, a black male was 20 percent as likely as a white male to be employed as a manager; 30 percent as likely to be employed in sales; and 40 percent as likely to work in a professional occupation. By 2001, these percentages had climbed to 60 percent, 70 percent, and 70 percent, respectively. At the

\footnotetext{
${ }^{8}$ These differentials in educational attainment may reflect different preferences and choices, and/or they may reflect pre-market differences in access to education, see Altonji and Blank (1999).
} 
same time the share of black males working as farm and nonfarm laborers fell, both absolutely and relative to whites. However, even with such progress, in 2001, black men were more likely to work in occupations requiring less skill and paying lower wages (e.g., clerical and operatives) than whites and less likely to be in occupations reaping the highest returns in the labor market (i.e., professional and managerial). Again, the patterns are similar for black men with less than ten years of experience. In tabulations not shown here, we find similar convergence among in the distribution of blacks and whites across 2-digit industry classifications. ${ }^{9}$

\section{Economy-Wide Wage Inequality}

As Juhn, Murphy, and Pierce (1991) point out, another important variable in explaining movements in the black-white wage gap is changes in the level of overall wage inequality. As the authors note, if blacks are disproportionately located in the lower end of the skill distribution (measured or unmeasured) then increasing disparity in the returns to skill will hinder black-white wage convergence. For instance, given that black males have less education than whites and continue to be disproportionately located in lower-paying occupations, they will be penalized by increases in the prices of measured skills (i.e., returns to education) and increases in the returns to particular sectors of the economy. In addition, if labor market discrimination or actual differences in unmeasured skills of blacks are present, then increasing returns to unmeasured skills will put additional downward pressure on the relative wages of blacks.

To review the patterns of male wages during the 1970s and 1980s and to document changes in those patterns in the 1990s, Figure 4 displays trends in the distribution of weekly

${ }^{9} \mathrm{~A}$ complete set of employment proportions by race and industry are available from the authors upon request. 
earnings for men. ${ }^{10}$ We display the median, the coefficient of variation, and the Gini and Theil coefficients. After declining almost steadily since 1978, the real median wage of males began to climb in 1993. By 1998, the median had surpassed the peak achieved in 1973. The three measures of dispersion in the figure exhibit nearly monotonic increases between 1967 and 1993, with the net increase ranging from 29 percent for the Gini coefficient to 55 percent for the Theil coefficient. In the latter half of the 1990s, dispersion decline somewhat, indicating growth in yearly male earnings that was more evenly distributed than it had been in past decades. The slowing economy in late 2000 and 2001 was accompanied by increases in dispersion, consistent with previous history.

The measures displayed in Figure 4 show that overall dispersion increased rapidly from about 1973 through 1993, leveled off and even declined somewhat during the 1990s, and then began to rise again in the late 1990s and in 2000-2001. Figure 5, panels A and B show a similar pattern for within-group wage dispersion; the figure displays relative wage trajectories of college-educated workers and high school graduates at the $10^{\text {th }}, 50^{\text {th }}$, and $90^{\text {th }}$ percentiles of the wage distribution for the 30 plus years in our sample. Each of the series is indexed to zero in 1968. Looking first at panel B-college graduates-over the past 30 years, workers at the $10^{\text {th }}$ percentile experienced wage reductions while those at the $50^{\text {th }}$ and $90^{\text {th }}$ percentiles experienced net wage increases. While it is clear from looking at the figure that the distribution of wages for college graduates has widened, it is also clear that wages of workers at the $10^{\text {th }}$ percentile of the distribution have recovered sharply since the recession of the early 1990s. Panel A depicts similar information for high school graduates. Wages at the $10^{\text {th }}$ and $50^{\text {th }}$ percentiles have

\footnotetext{
${ }^{10}$ This measure includes individuals whose yearly earnings are zero.
} 
decreased during the period covered by the sample. Since the recession of the early 1990 s, the earnings of all groups have been increasing, with the sharpest gains in the last several years experienced by workers at the bottom of the distribution.

Combined, the trends on economy-wide male wage inequality indicate a potential role for changes in the returns to both observed (measured as between-group wage dispersion) and unobserved (measured as within-group wage dispersion) skills. To get a sense of how important they might be, Table 3 shows the position of whites in the black wage distribution. The table reports the percentage of whites earnings less than blacks at various points in the black wage distribution. For example, the first row of the table shows the percentage of whites earning less than blacks at the $10^{\text {th }}$ percentile of the black wage distribution; equality between blacks and whites would mean that this percentage would equal 10 percent. The last column of the table shows the averages for all individuals in all years. ${ }^{11}$

The table indicates that, over time, the distribution of black wages has become more like that of whites, although considerable progress has yet to be made before they are equal. For example, in the first year of our sample, 1968, only seven percent of whites earned less than the bottom quarter of black workers. By 2001, 17 percent of whites earned less than the bottom quarter of black workers. Similarly, in 1968, 63 percent of whites earned less than the $90^{\text {th }}$ percentile of black wages. In 2001, 81 percent of whites earned less than the $90^{\text {th }}$ percentile of black wages.

\footnotetext{
${ }^{11}$ Note that the percentages reported in the last column are not averages of the elements in that row, but averages for the percentile across all years and individuals.
} 
The descriptive evidence suggests that blacks should be gaining relative to whites as they move up through the white distribution of wages. However, given the continued overrepresentation of blacks in the lower end of the wage distribution, the increase in economywide wage inequality, documented in Figures 4 and 5, could be expected to disproportionally affect black workers, partially offsetting any gains realized through improvements in observable and/or unobservable skill and lessening of labor market discrimination.

\section{Assessing the Importance of Specific Factors}

Analytic Methodology

To assess the importance of each of the various factors thought to affect the black-white wage gap we use a decomposition technique developed by Juhn, Murphy, and Pierce (1991), hereafter JMP, which extends the now standard decomposition technique proposed by Oaxaca (1973). The innovation in the JMP extension is to decompose the "unexplained" or "residual" portion of the wage gap from the Oaxaca decomposition into a price and quantity component. This, in turn, allows one to fully partition changes in the unadjusted wage gap into portions associated with measured and unmeasured characteristics and returns to these characteristics. This technique has been used by Blau and Kahn (1992; 1994) to examine gender wage gaps and by Rodgers (1997) to look at differences in black-white wage gaps across cities and suburbs. Our brief description of the model closely follows that of the cited authors. A very detailed discussion of this technique can be found Altonji and Blank (1999).

The decomposition can be described as follows. Suppose we have a white male wage equation for worker $I$ in year $t$.

$$
\mathrm{Y}_{\mathrm{it}}=\mathrm{X}_{\mathrm{it}} \mathrm{B}_{\mathrm{t}}+\sigma_{\mathrm{t}} \theta_{\mathrm{it}}
$$


where $\mathrm{Y}_{\mathrm{it}}$ is the log weekly wage; $X_{i t}$ is a vector of explanatory variables; $B_{t}$ is a vector of coefficients; $\theta_{i t}$ is a standardized residual (i.e., with mean 0 and variance 1 for each year); and $\sigma_{t}$ is the residual standard deviation of white male wages for that year (i.e., the unexplained level of male wage inequality in year t). ${ }^{12}$

Then, following standard decomposition techniques, the black-white log weekly wage gap for year $t$ can be written as:

$$
\mathrm{D}_{\mathrm{t}} \equiv \mathrm{Y}_{\mathrm{wt}}-\mathrm{Y}_{\mathrm{bt}}=\Delta \mathrm{X}_{\mathrm{t}} \mathrm{B}_{\mathrm{t}}+\sigma_{\mathrm{t}} \Delta \theta_{\mathrm{t}}
$$

where the $w$ and $b$ subscripts refer to white and black averages, respectively, and a $\Delta$ prefix signifies the average white-black difference for the variable immediately following. Equation (2) states that the wage gap can be decomposed into race differences in measured variables $\left(\Delta X_{t}\right)$ and race differences in the standardized residual $\left(\Delta \theta_{t}\right)$ from the white equation multiplied by the log money value per unit difference in the standardized residual $\left(\sigma_{t}\right)$.

The difference in the black-white wage differential between two years $(0$ and 1$)$ can then be decomposed using equation (2) as follows:

$$
\mathrm{D}_{\mathrm{t}^{\prime}}-\mathrm{D}_{\mathrm{t}}=\left(\Delta \mathrm{X}_{\mathrm{t}^{\prime}}-\Delta \mathrm{X}_{\mathrm{t}}\right) \mathrm{B}_{\mathrm{t}}+\Delta \mathrm{X}_{\mathrm{t}^{\prime}}\left(\mathrm{B}_{\mathrm{t}^{\prime}}-\mathrm{B}_{\mathrm{t}}\right)+\left(\Delta \theta_{\mathrm{t}^{\prime}}-\Delta \theta_{\mathrm{t}}\right) \sigma_{\mathrm{t}}+\Delta \theta_{\mathrm{t}^{\prime}}\left(\sigma_{\mathrm{t}^{\prime}}-\sigma_{\mathrm{t}}\right)
$$

The expression decomposes the total change in the black-white wage gap between two years into four components. The first term in (3) reflects the contribution of changes in measured characteristics holding prices fixed. The second term reflects the impact of changing prices for observed variables holding measured characteristics fixed. The third term measures the effect of

\footnotetext{
${ }^{12}$ The standard formulation would be $\mathrm{Y}_{\mathrm{it}}=\mathrm{X}_{\mathrm{it}} \mathrm{B}_{\mathrm{it}}+\mu_{\mathrm{it}}$. JMP begin by expressing $\mu_{i t}$ as the multiple of its standard deviation $\sigma_{i t}$ and a standardized residual, $\theta_{i p}$, equal to $\mu_{i t} / \sigma_{i t}$. 
changing differences in the relative wage positions of blacks and whites after controlling for measured characteristics (i.e., whether blacks rank higher or lower within the white residual distribution). ${ }^{13}$ Finally, the fourth term of equation (3) reflects the impact of changes in residual male wage inequality between the two years. ${ }^{14}$ This term measures the contribution to the change in the black-white wage gap associated with changes in the distribution of male residual wages, holding blacks' position in that distribution constant. As JMP note, if earnings inequality is increasing within each observable skill category, as it was during the 1980s, this will adversely affect blacks even in the absence of other changes because blacks are already concentrated in the lower part of the earnings distribution.

\section{Empirical Strategy}

We implement this decomposition using a model of wage determination that includes controls for age, education, potential experience, region of residence, whether the individual is a private or public sector worker or self-employed, and dummy variables for industry (2-digit) and occupation (1-digit). The inclusion of occupation and industry in these types of models is a subject of considerable debate. We include industry and occupation in our model but separate the effects of education and experience from industry and occupation to allow readers to see clearly the contribution that each variable makes. Education is measured as a set of dummy variables representing no high school degree, high school degree, and some college; college

\footnotetext{
${ }^{13}$ As JMP point out, changes in the rankings of blacks in the white distribution may reflect changes in unmeasured characteristics of blacks or changes in labor market discrimination against blacks.

${ }^{14}$ JMP refer to the third and fourth terms as the "gap" and the "unobservable price effect". The gap shows how much of the change in the total residual is due to blacks moving up or down the distribution of whites for any given set of observables. The unobservable price effect shows how much is due to general changes in wage inequality that affect blacks more than whites because they are disproportionately located in the bottom of the residual distribution.
} 
graduates are the omitted group. In addition, we include the total amounts of schooling for those with less than a high school degree or some college. Potential experience is entered as a quartic. Region of residence is defined by the Census divisions: northeast, north central, south, and west; northeast is the excluded region in our regressions.

While the first and second terms of equation (3) come easily from a standard regression, the third and fourth terms are obtained more nonparametrically in the following manner. Following JMP, we obtain the third term, $\left(\Delta \theta_{t^{\prime}}-\Delta \theta_{t}\right) \sigma_{t}$, by assigning to each black male in each year a percentile number corresponding to his position in the white residual wage distribution for that year. ${ }^{15}$ We then compute an imputed $t^{\prime}$ mean black residual based on the black percentile rankings in $t^{\prime}$ and the distribution of male earnings in $t$. The difference between the imputed black wage residual in $t^{\prime}$ and the actual black wage residual in $t^{\prime}$ allows us to estimate $\left(\Delta \theta_{t^{\prime}}\right.$ $\left.\Delta \theta_{t}\right) \sigma_{t}$. Again, this term measures movement of blacks through the white residual wage distribution between periods. If there is no such movement, this term is zero.

The fourth term is calculated analogously. Once again, we assign percentiles of the white distribution to each black in year $t^{\prime}$, compute what residual that black would have had in year $t^{\prime}$ given that position in the white distribution, and subtract that from the actual black $t^{\prime}$ residual. Since the percentile locations of blacks are held fixed in this calculation, the difference in the two residuals reflects only changes in residual inequality for whites.

We estimate these effects for all years, by comparing a given year $t^{\prime}$ to the average throughout the sample. We summarize the results across three time intervals: 1968-1979,

\footnotetext{
${ }^{15}$ Other useful descriptions of the JMP technique can be found in Blau and Kahn $(1992,1994)$, Rodgers (1997), and Altonji and Blank (1998).
} 
1979-1989, and 1989-2001. For each period we estimate the average annual rate of change in each component by estimating a linear spline with break points at 1979 and 1989. We organize the results in two ways, first by the contributions of the measured and unmeasured factors, and second by the contributions of individual characteristics (i.e., the first and third terms of the decomposition) and the contributions of overall wage inequality (i.e, the second and fourth terms of the decomposition).

Results

Before considering the magnitude and statistical significance of each of the four terms in equation (3) it is useful to view the time series of the actual and adjusted black-white wage gap. Figure 6 shows the total wage gap and the residual wage gap, once differences in observables (the first two terms of equation (3)) are accounted for. The vertical difference in the two lines represents the reduction in the black-white wage differential that would occur if all observable factors included in the regression were equalized across blacks and whites. Over the course of our sample period, both the actual and residual gap decline. For the sample of workers with less than ten years of potential experience, the reduction in the actual gap was slightly more pronounced than the reduction in the residual gap (i.e., the vertical difference between the two gaps narrowed). This implies that for younger workers, the equalization of black and white observable characteristics would reduce the black-white wage gap by less today than it would have 30 years ago.

Table 4 provides a much more detailed description of the trends in Figure 6. The table shows the contribution of each factor to the annual percentage point trend in the black-white weekly earnings gap, as estimated by our decomposition analysis. Panel A reports results for 
men at all levels of experience; panel B shows results for relatively new entrants to the labor market.

The first line in the table, panel A, labeled "overall trend," shows the estimated trend in the differential, without controlling for education, experience, occupation, and industry, for men of all experience levels. Between 1968 and 1979, the differential between black and white wages declined by an average of 1.2 percentage points per year. During the next decade, the wage gap increased by .24 percentage point per year. During the 1990s, however, the black-white wage differential began to decline again, falling by .59 percentage point per year between 1989 and 2001.

Adding human capital and employment structure variables to this model significantly affects the trends in the wage gap, particularly in the 1970s and 1990s. Looking first at the human capital variables, about $30 \%$ of the wage convergence observed between 1968-1979 and 1989-1998 is attributable to changes in education and experience. Decomposing the overall human capital contribution into separate quantity and price effects, we find different effects in different periods. In the first period, changes in the distribution of education and experience played the largest role. During the 1980s, gains among blacks in education and experience were nearly completely offset by the wage penalties associated with increasing returns to skill. In the 1990s, the stabilization of between-group income inequality and additional gains in education and experience among blacks worked together to reduce the black-white wage differential during the period.

The patterns for the employment structure variables are similar, with the largest effects occurring in the first and last decades of our sample period. Decomposing the total employment 
structure effect into the quantity and price components shows that equalization in the employment distribution positively affected the relative wages of blacks between 1969-1979 and 1989-2001. In the earliest period, these changes in the employment distribution were boosted by increases in the relative pay of occupations filled by blacks. In contrast, during the 1990s, the positive effects of more equal employment distribution were partially offset by the fact that blacks continue to be located disproportionately in occupations with falling relative pay.

Even with the inclusion of a full set of measured characteristics, a sizeable amount of the black-white wage differential remains unexplained, particularly during the 1980s and 1990s. Breaking this unexplained portion into its price and quantity components reveals a number of interesting results. First, consistent with other researchers, we find that returns to unobserved skills penalized blacks in the 1970s, a period of rising within-group income inequality. This penalty was more than offset by convergence in the distribution of unobservable skills and/or the lessening of labor market discrimination during the period. In contrast, during the 1980s, prices played a limited role, and differences in unobserved skills and/or increases in discrimination widened the black-white wage gap. In the 1990s, the pattern appears to have returned to the earlier decade, with returns to unobservable skills (within-group wage inequality) exacting some penalty, but that being more than offset by convergence in the distributions of unobserved skills for blacks and whites and/or a lessening of labor market discrimination.

Overall, for workers at all experience levels, the portion of wage convergence explained by measured characteristics has declined over time, although it was higher in the latest period (38\%) than in the 1980s (25\%). Considering the convergence in the context of changes in racespecific factors versus changes in the wage structure, we find that, in general, changes in race- 
specific factors had a larger impact than changes in the wage structure. That being said, wage inequality did exact a considerable toll on black-white wage convergence during the 1980s and continued to be a factor inhibiting the closure of the gap during the 1990s.

Among workers with less than ten years of labor market experience, the historical pattern of change in the total wage gap is similar to that for all workers. Between 1968 and 1979, the wage gap converged at an average of 1.33 percentage points a year. During the 1980s, the gap widened at an annual rate of 0.61 percentage point per year. The rate of convergence during the 1990s has been solid, with the wage gap closing at a rate of 1.19 percent percentage points per

year. In terms of the factors influencing convergence, much like the larger group of all workers, equalization of the distributions of employment by industry and occupation explains 0.34 of the 1.40 percentage point per year decline in inequality. The largest factor influencing the reduction in the wage gap, however, is a decline in the residual, which would account for a 0.84 percentage point reduction in the gap since 1990. Within that decline, the most important factor appears to be an equalization in the quantity of unobservable skills between blacks and whites and/or a lessening of labor market discrimination.

\section{Conclusions}

During the 1990s and into the new century, the relative status of black male workers began to improve, marking the end of a long period of stasis and even regression. The rate of convergence of wages among all male workers observed during the period from 1989-2001 was .59 percentage point per year. The rate of convergence for younger workers was more rapid at 1.19 percentage points per year. For both groups, improved educational attainment and greater industry and occupational diversification helped reduce the gap. Greater convergence in 
unobservable skills and/or a reduction in labor market discrimination also played a role in the improved relative status of black men. That said, economy-wide wage inequality continued to temper the convergence in black-white wages, although its impact was less important than in the previous decades. 


\section{References}

Altonji, J. and R. Blank, 1999, Race and gender in the labor market, in: O. Ashenfelter and D. Card, eds., Handbook of labor economics (Elsevier, New York) 3143-3260.

Blau, F. and L. Kahn, 1992, The gender earnings gap: Learning from international comparisons, American Economic Review, May, 533-38.

Blau, F. and L. Kahn, 1994, Rising wage inequality and the U.S. gender gap, American Economic Review, May, 23-28.

Bound, J. and R. Freeman, 1992, What went wrong? The erosion of relative earnings and employment among black men in the 1980s, Quarterly Journal of Economics 107, 371-392.

Brown, C., 1982, The federal attack on labor market discrimination: The mouse that roared?, Research in Labor Economics, 33-68.

Card, D. and A.B. Krueger, 1992, School quality and black-white relative earnings: A direct assessment, Quarterly Journal of Economics 107, 151-200.

Donohue, J.J. and J.J. Heckman, 1991, Continuous versus episodic change: The impact of civil rights policy on the economic status of blacks, Journal of Economic Literature 29(4), 1603-1643.

Heckman, J.J. and B. Payner, 1989, Determining the impact of federal antidiscrimination policy on the economic status of blacks: A study of South Carolina, American Economic Review 79(1), 139-177.

Heckman, J.J., T.M. Lyons, and P.E. Todd, 2000, Understanding black-white wage differentials, 1960-1990, American Economic Review 90(2), 344-349.

Jaynes, G.D., 1990, The labor market status of black Americans: 1939-1985, Journal of Economic Perspectives 4(4), 9-24.

Juhn. C., K. Murphy, and B. Pierce, 1991, Accounting for the slowdown in black-white wage convergence, in: M.H. Kosters, ed., Workers and their wages: Changing patterns in the United States, (AEI Press, Washington, DC) 107-143.

Leonard, J.S., 1990, The impact of affirmative action regulation and equal employment law on black employment, Journal of Economic Perspectives 4(4), 47-63.

Oaxaca, R., 1973, Male-female wage differentials in urban labor markets, International Economic Review, October, 693-709.

Rodgers, W.M., 1997, Male sub-metropolitan black-white wage gaps: New evidence for the 1980s, Urban Studies 34(8), 1201-1213.

Smith, J.P. and F. Welch, 1977, Black-white male wage ratios, 1960-1970, American Economic Review 67(3), 323-328. 
Smith, J.P. and F. Welch, 1984, Affirmative action and labor markets, Journal of Labor Economics 27(2), 269-301.

Smith, J.P. and F. Welch, 1989, Black economic progress after Myrdal, Journal of Economic Literature, 27(2), 519-564.

Welch, F., 2003, Catching up: Wages of black men, American Economic Review 93(2), 320-325. 
Figure 1. Black-White Weekly Earnings Differential, 1968-2001

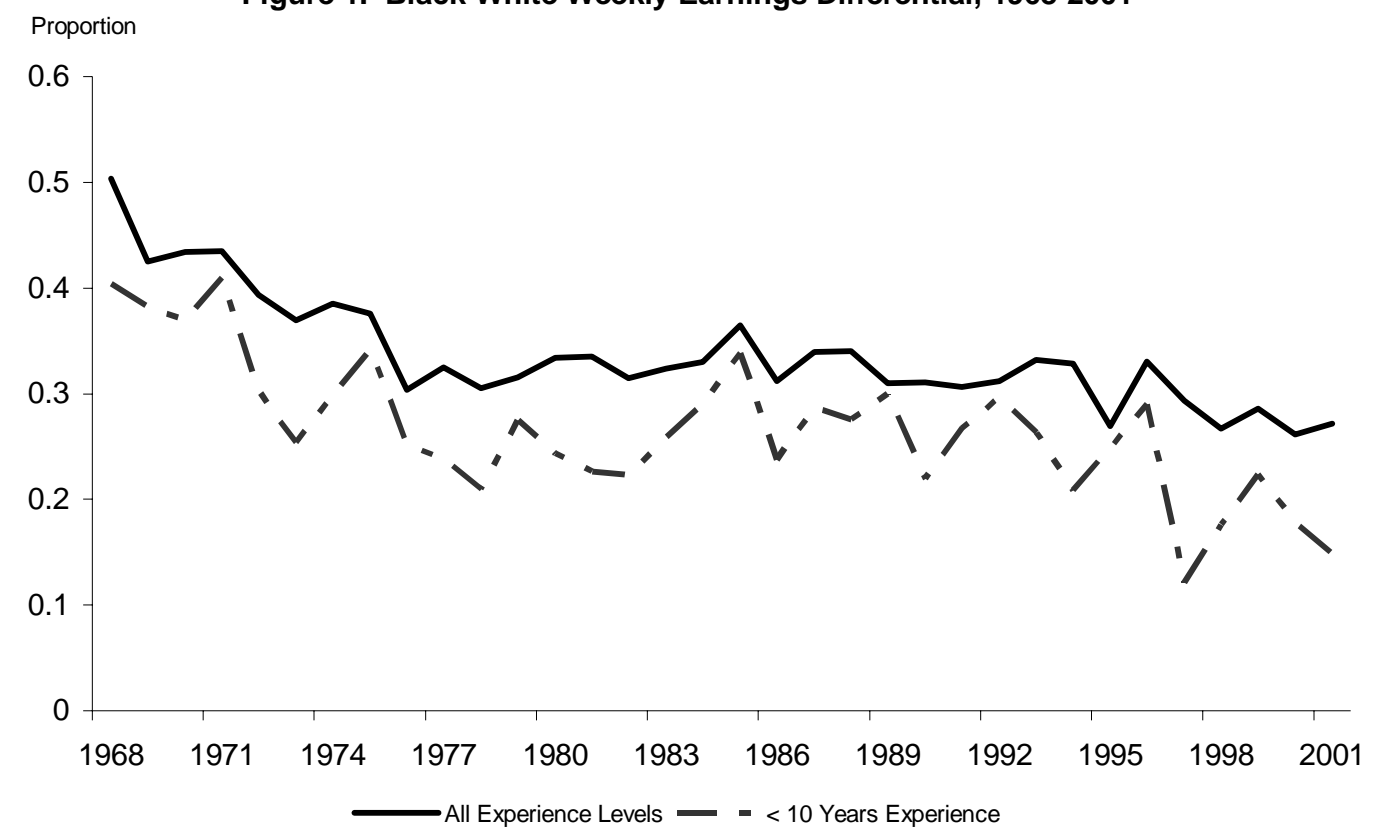

Notes: Experience=Potential experience, calculated as min[age-education-6, age-18]

Source: Authors' calculations using March CPS, 1969-2002. 


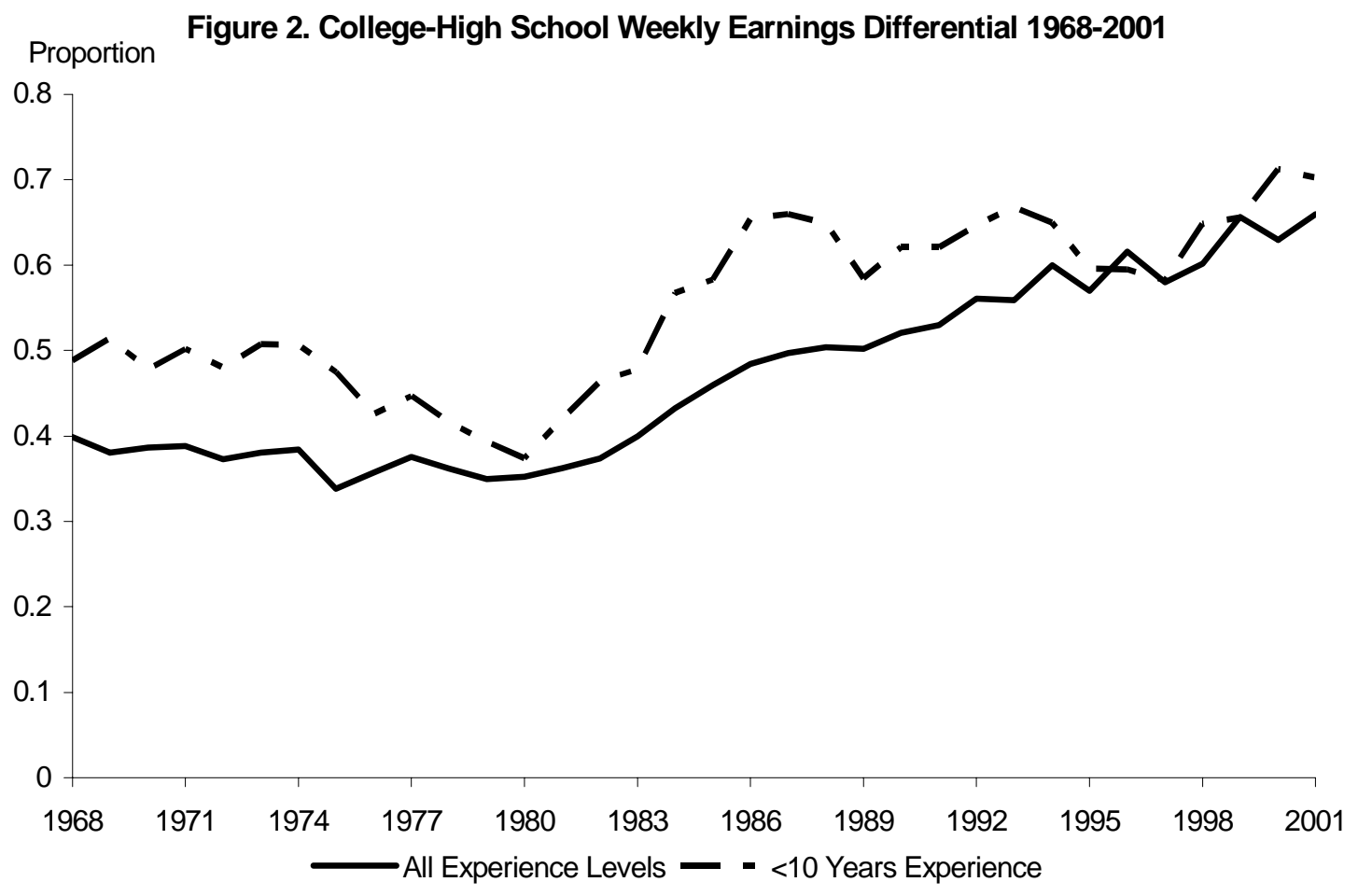

Source: Authors' calculations using March CPS. 1969-2002.

Figure 3. Average Weekly Earnings in 2001 by Major Occupation Groups

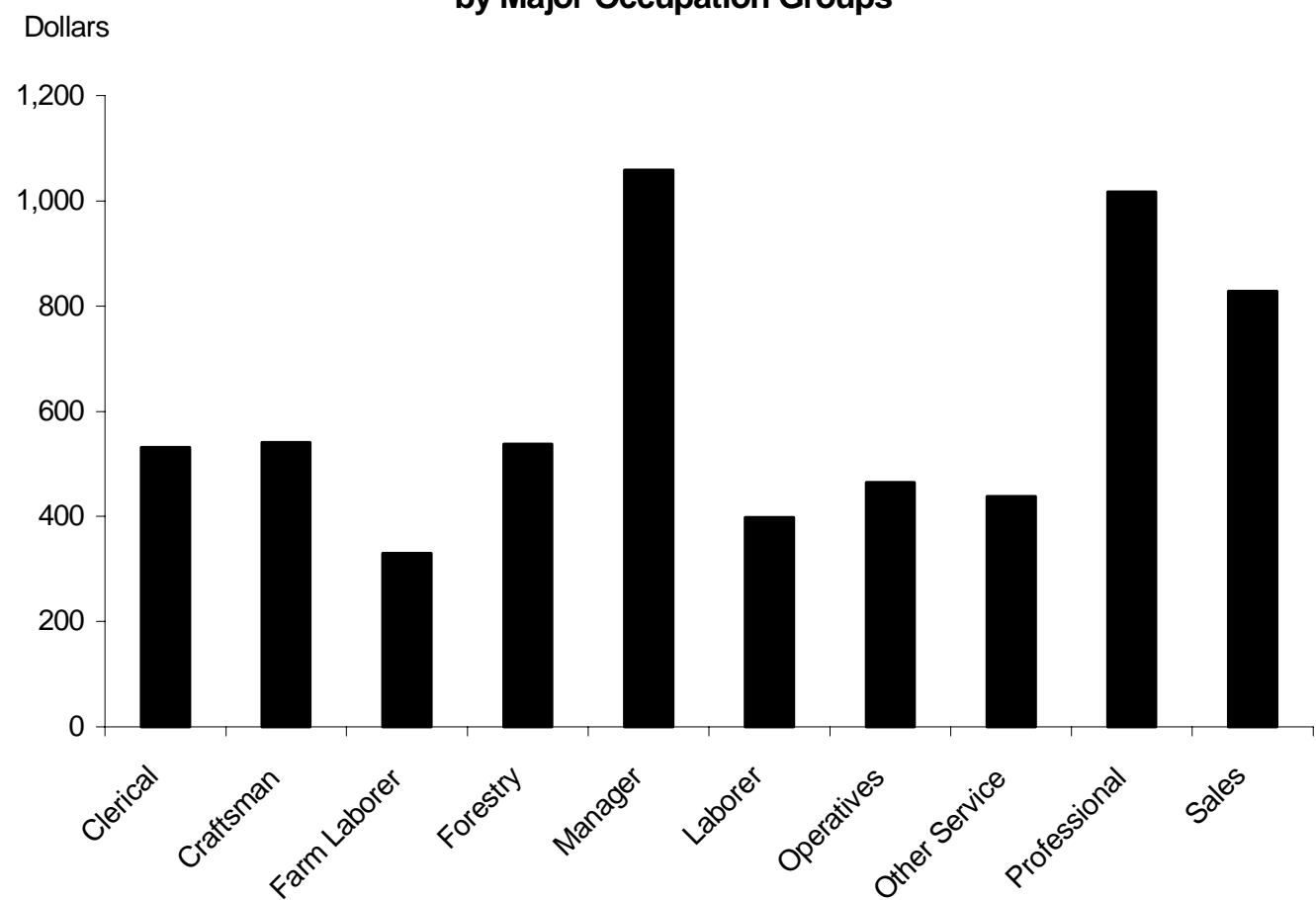

Source: Authors' calculations using March CPS, 1969-2002. 
Figure 4. Summary Measures of Male Earnings Distribution, 1968-2001

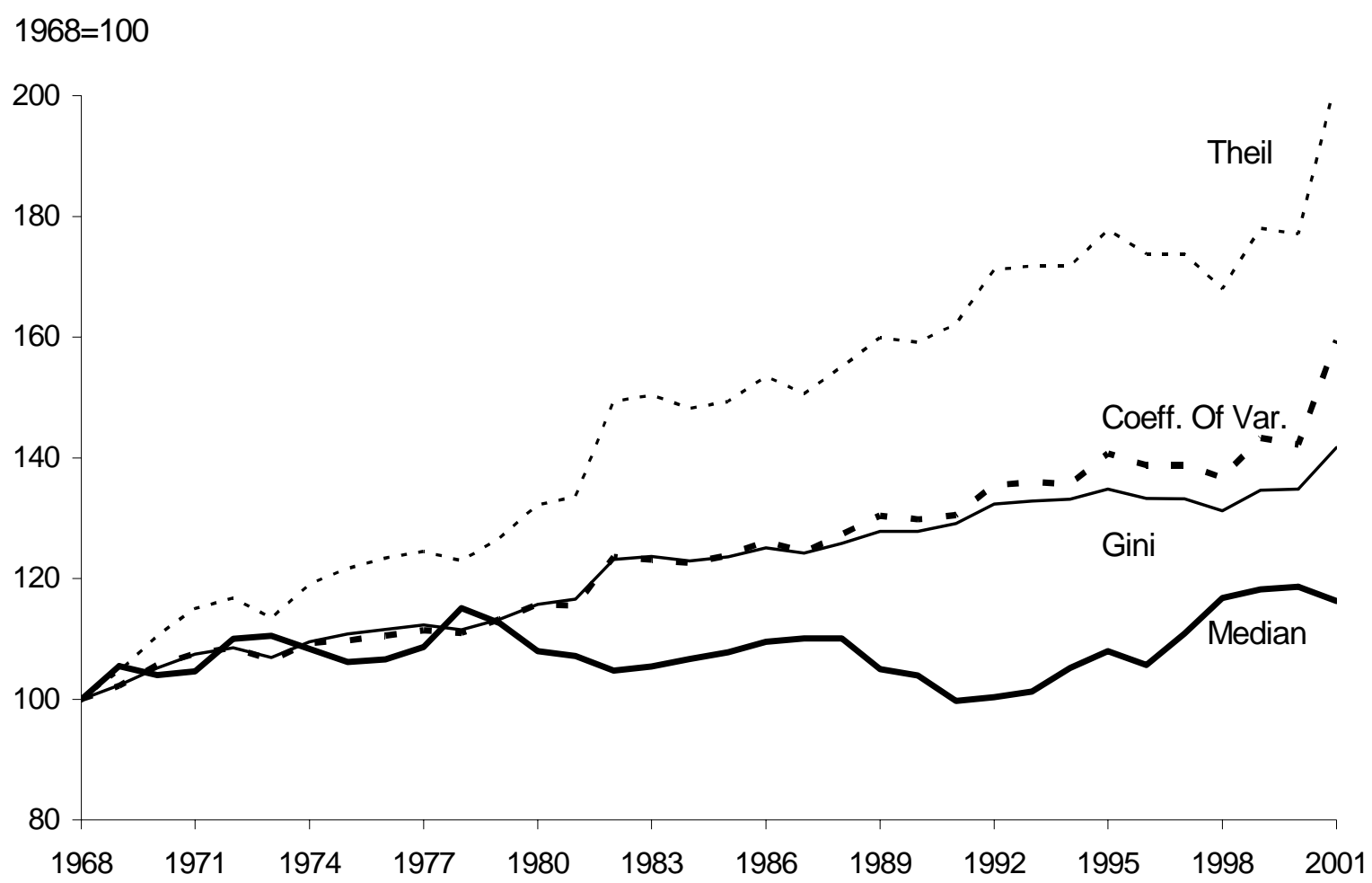

Source: Author's calculations using March CPS, 1969-2002 
Figure 5. Trends in Wage Dispersion

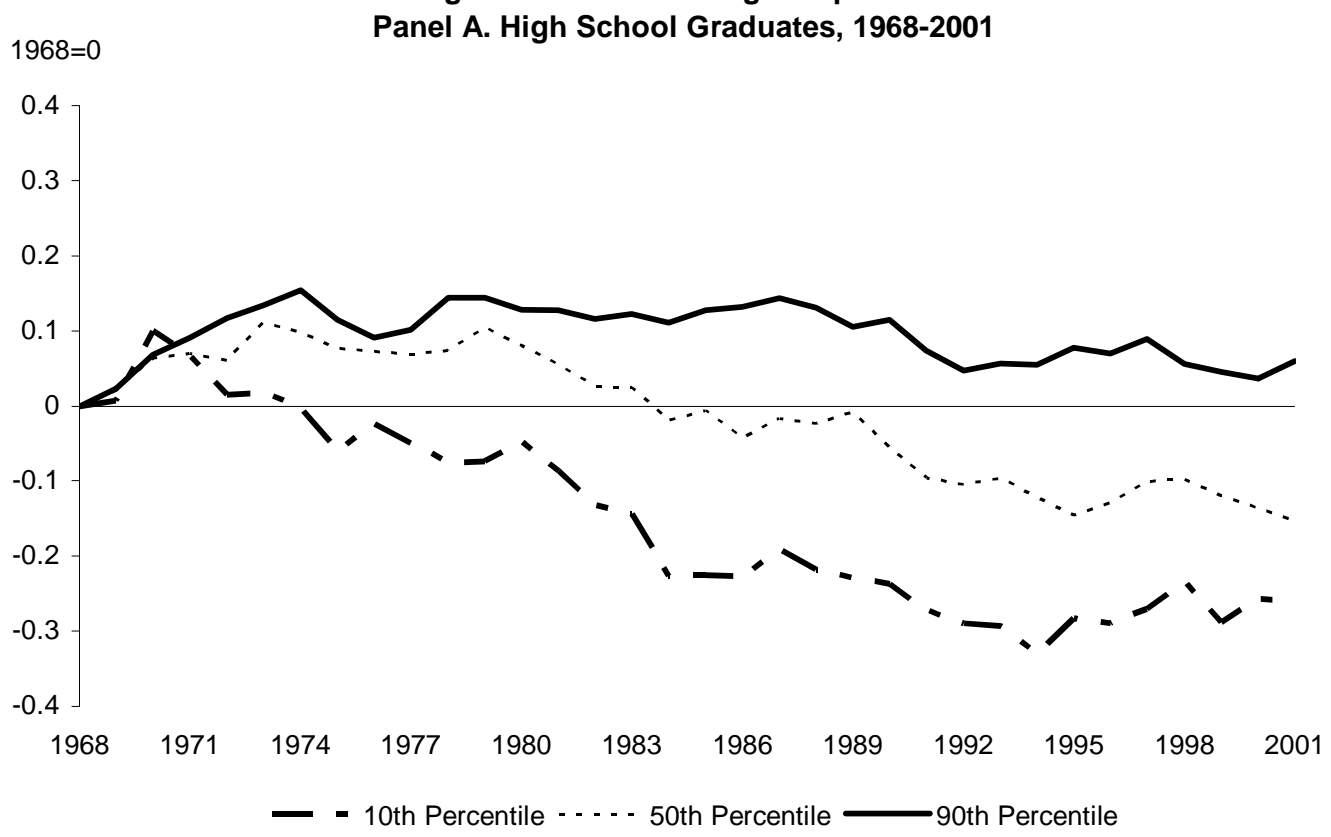

$1968=0$

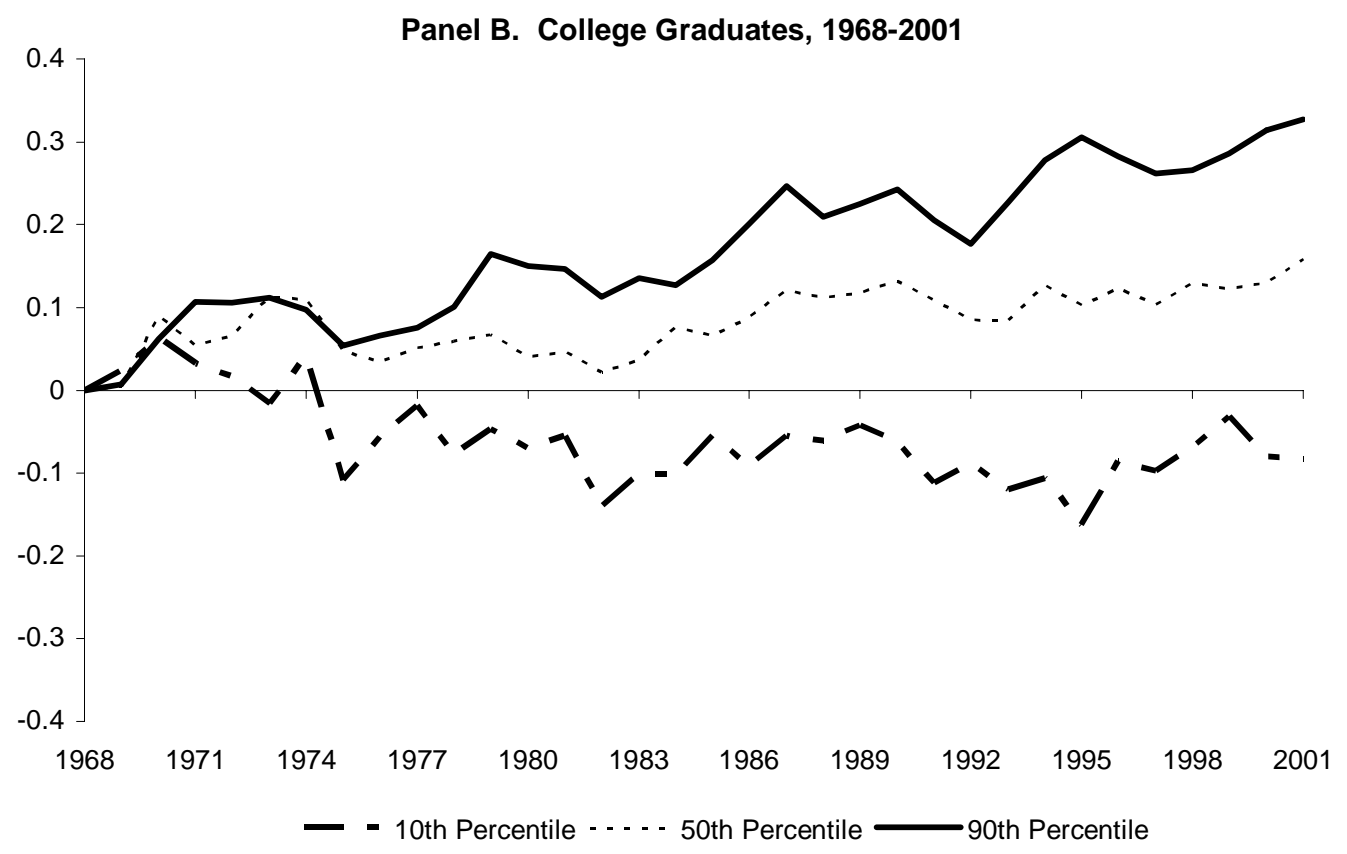




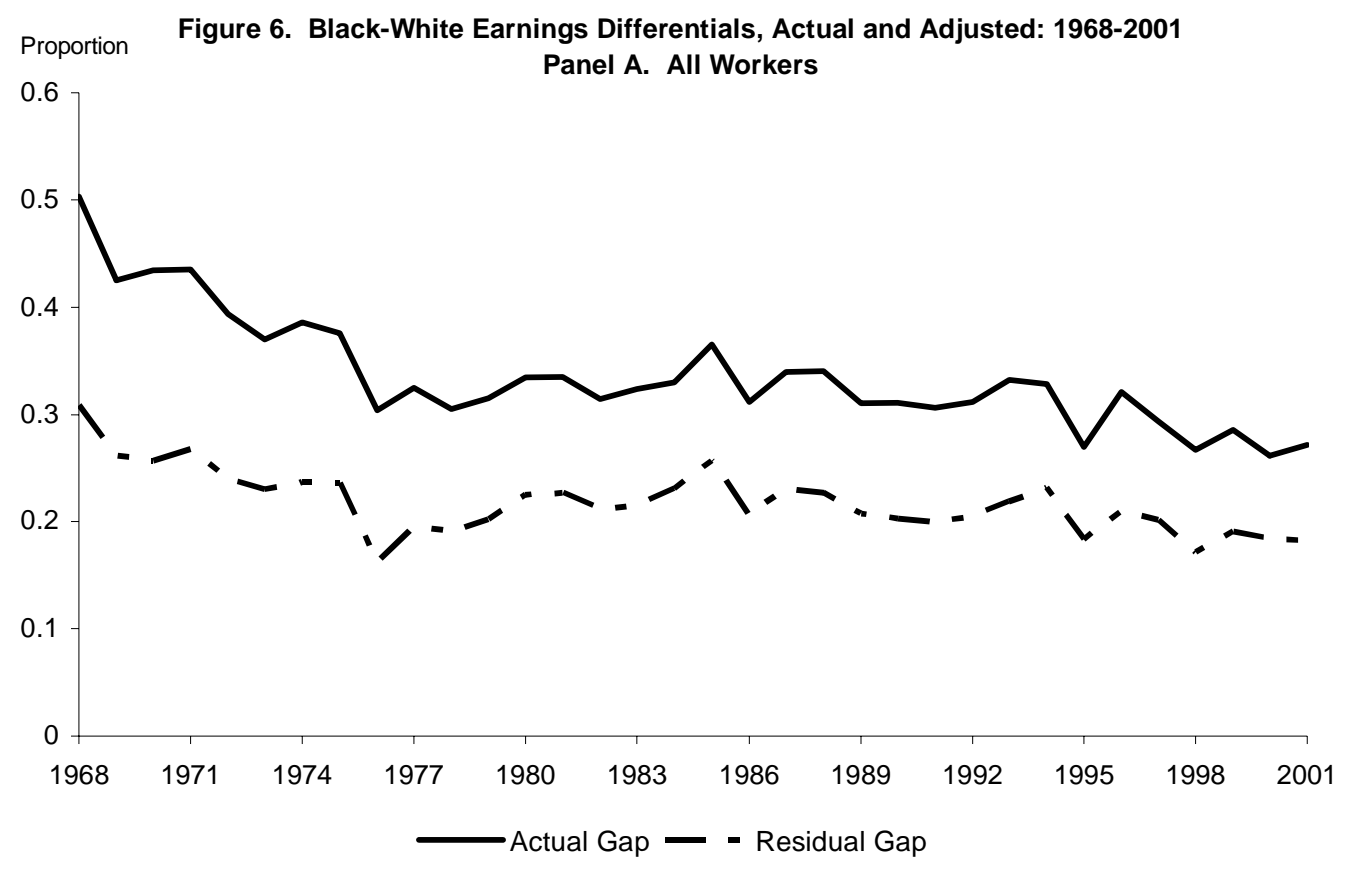

Panel B. Workers with $<10$ Years of Potential Experience

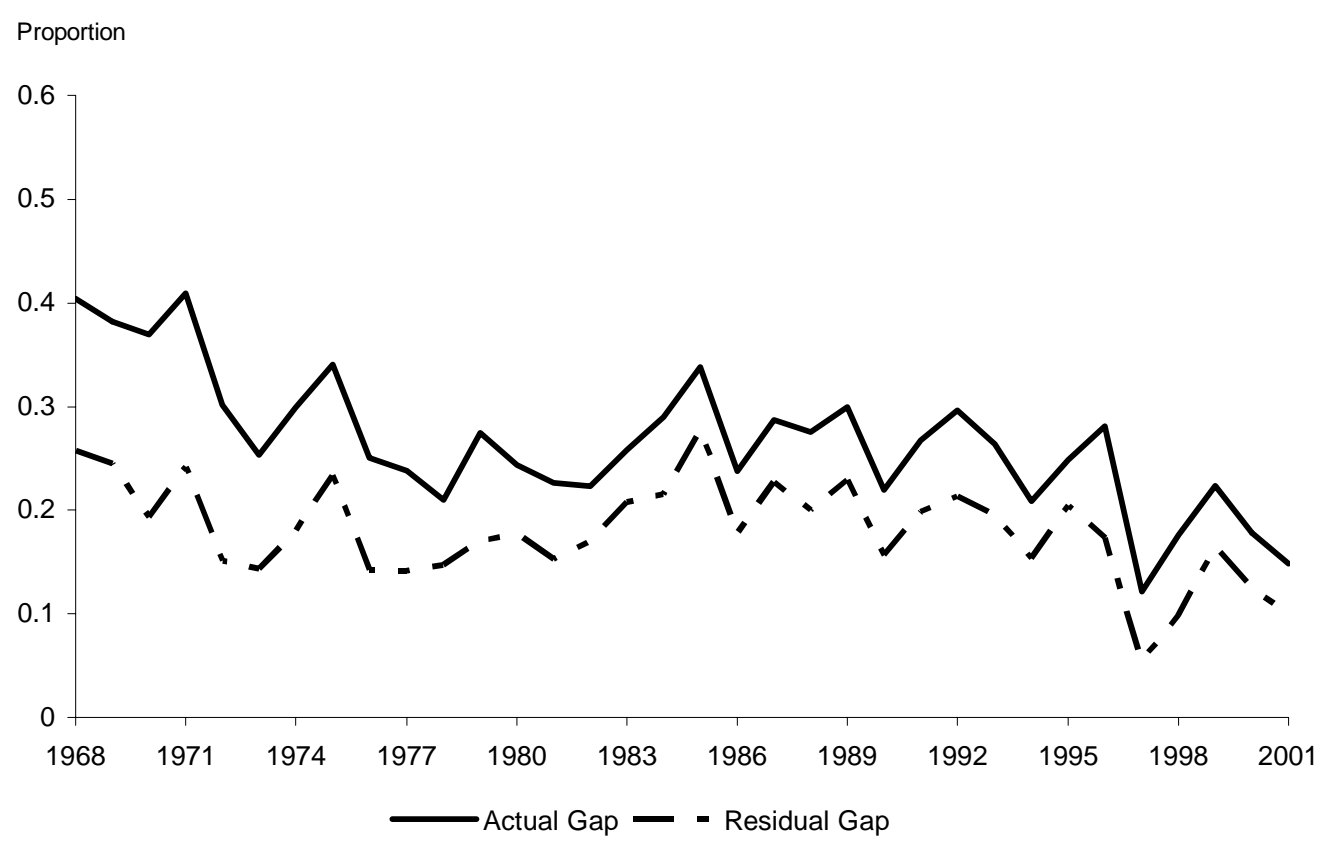

Source: Authors' calculations using March CPS, 1969-2002. 
Table 1. Black-White Weekly Earnings Differentials, 1968-2001, by Potential Experience

\begin{tabular}{|c|c|c|c|c|c|c|c|c|}
\hline Experience Levels & 1968-1972 & 1973-1977 & $1978-1982$ & 1983-1987 & 1988-1992 & 1993-1997 & 1998-2001 & $\begin{array}{c}\text { Row } \% \text { Change } \\
\text { First to Last } \\
\text { Period }\end{array}$ \\
\hline All Levels & .4383 & .3518 & .3208 & .3339 & .3159 & .3089 & .2714 & $38 \%$ \\
\hline$<6$ & .3602 & .2475 & .2306 & .2919 & .2499 & .1840 & .2007 & $44 \%$ \\
\hline $6-10$ & .3991 & .3239 & .2487 & .2760 & .3003 & .2865 & .1862 & $53 \%$ \\
\hline $11-15$ & .4294 & .3426 & .3415 & .3333 & .3241 & .2729 & .2685 & $38 \%$ \\
\hline $16-20$ & .4786 & .3817 & .3272 & .3063 & .3058 & .3771 & .2789 & $41 \%$ \\
\hline $21-25$ & .4807 & .4349 & .3590 & .3266 & .3056 & .3598 & .3023 & $37 \%$ \\
\hline $26-30$ & .4585 & .3866 & .4094 & .4015 & .3198 & .3129 & .3454 & $25 \%$ \\
\hline $31-35$ & .4543 & .4197 & .4818 & .4498 & .3745 & .3326 & .3209 & $29 \%$ \\
\hline$>35$ & .4528 & .3826 & .3592 & .4003 & .3442 & .2769 & .2504 & $45 \%$ \\
\hline
\end{tabular}

Notes: Potential experience $=\min [$ age-education-6,age-18]

Source: Authors' calculations using March CPS, 1969-2002 
Table 2. Changes in the Relative Representation of Blacks Across Education and Occupational Groups

\begin{tabular}{|c|c|c|c|c|c|c|c|c|c|c|}
\hline \multicolumn{11}{|c|}{ Panel A. All Experience Levels } \\
\hline & \multicolumn{2}{|c|}{1968} & \multicolumn{2}{|c|}{1979} & \multicolumn{2}{|c|}{1989} & \multicolumn{2}{|c|}{1995} & \multicolumn{2}{|c|}{2001} \\
\hline & Percentage & $\begin{array}{l}\text { Relative } \\
\text { to Whites }\end{array}$ & Percentage & $\begin{array}{l}\text { Relative } \\
\text { to Whites }\end{array}$ & Percentage & $\begin{array}{l}\text { Relative } \\
\text { to Whites }\end{array}$ & Percentage & $\begin{array}{l}\text { Relative } \\
\text { to Whites }\end{array}$ & Percentage & $\begin{array}{l}\text { Relative } \\
\text { to Whites }\end{array}$ \\
\hline \multicolumn{11}{|c|}{ Education } \\
\hline Less than High School & 63.2 & 1.7 & 37.2 & 1.8 & 21.6 & 1.5 & 13.1 & 1.2 & 12.0 & 1.1 \\
\hline High School Degree & 25.6 & 0.7 & 39.2 & 1.0 & 45.4 & 1.2 & 42.0 & 1.3 & 41.9 & 1.3 \\
\hline Some College & 7.4 & 0.6 & 14.2 & 0.8 & 19.0 & 1.0 & 28.0 & 1.1 & 28.2 & 1.0 \\
\hline College Degree & 3.8 & 0.3 & 9.4 & 0.4 & 14.1 & 0.5 & 16.9 & 0.6 & 17.9 & 0.6 \\
\hline \multicolumn{11}{|c|}{ Occupation } \\
\hline Clerical & 7.9 & 1.0 & 7.1 & 1.1 & 8.8 & 1.7 & 9.2 & 1.8 & 7.5 & 1.5 \\
\hline Craftsman & 14.1 & 0.6 & 19.0 & 0.8 & 28.7 & 1.0 & 24.6 & 0.9 & 22.8 & 0.9 \\
\hline Farm Laborer/Manager & 4.3 & 3.3 & 2.5 & 2.2 & 2.9 & 1.5 & 1.8 & 0.9 & 1.3 & 0.6 \\
\hline Forestry & 0.2 & 1.0 & 0.2 & 0.9 & 0.2 & 1.1 & 0.4 & 0.3 & 0.8 & 0.5 \\
\hline Manager & 2.4 & 0.2 & 5.7 & 0.4 & 8.8 & 0.4 & 11.0 & 0.5 & 13.1 & 0.6 \\
\hline Nonfarm Laborer & 19.3 & 4.0 & 13.6 & 2.6 & 5.5 & 2.2 & 5.0 & 1.8 & 4.3 & 1.6 \\
\hline Operative & 30.1 & 1.4 & 28.4 & 1.5 & 18.4 & 2.0 & 16.5 & 1.8 & 17.0 & 1.8 \\
\hline Other Services & 14.2 & 2.7 & 13.7 & 2.1 & 14.2 & 2.0 & 15.1 & 2.0 & 16.3 & 2.1 \\
\hline Professional & 5.9 & 0.4 & 7.7 & 0.5 & 8.7 & 0.5 & 10.4 & 0.6 & 11.4 & 0.7 \\
\hline Sales & 1.4 & 0.3 & 2.0 & 0.4 & 3.0 & 0.5 & 4.0 & 0.6 & 4.5 & 0.7 \\
\hline
\end{tabular}


Panel B. Less Than Ten Years of Potential Experience

\begin{tabular}{|c|c|c|c|c|c|c|c|c|c|}
\hline 1968 & & 197 & & 19 & & 195 & & 200 & \\
\hline Percentage & to Whites & Percentage & to Whites & Percentage & to Whites & Percentage & to Whites & Percentage & to Whites \\
\hline
\end{tabular}

\begin{tabular}{|c|c|c|c|c|c|c|c|c|c|c|}
\hline Less than High School & 40.2 & 2.0 & 23.8 & 2.1 & 10.8 & 0.9 & 7.3 & 0.9 & 11.1 & 0.9 \\
\hline High School Degree & 42.8 & 1.0 & 45.8 & 1.2 & 49.6 & 1.3 & 42.1 & 1.3 & 38.5 & 1.3 \\
\hline Some College & 11.1 & 0.7 & 17.0 & 0.8 & 23.3 & 1.2 & 29.9 & 1.1 & 28.3 & 1.0 \\
\hline \multicolumn{11}{|c|}{ Occupation } \\
\hline Clerical & 11.5 & 1.2 & 9.8 & 1.7 & 9.5 & 1.6 & 12.5 & 2.4 & 8.4 & 1.6 \\
\hline Farm Laborer & 4.2 & 2.3 & 1.9 & 1.5 & 3.1 & 1.1 & 1.1 & 0.5 & 1.4 & 0.5 \\
\hline Forestry & 0 & 0 & 0.5 & 1.7 & 0.2 & 0.7 & 0.1 & 1.0 & 0 & 0 \\
\hline Manager & 3.4 & 0.4 & 4.9 & 0.4 & 7.4 & 0.5 & 8.9 & 0.5 & 12.8 & 0.8 \\
\hline Nonfarm Laborer & 28.8 & 1.2 & 15.2 & 2.4 & 6.5 & 2.0 & 5.7 & 1.6 & 4.0 & 1.1 \\
\hline Professional & 8.1 & 0.4 & 8.4 & 0.4 & 10.4 & 0.6 & 10.3 & 0.6 & 13.4 & 0.7 \\
\hline Sales & 2.3 & 0.4 & 2.5 & 0.4 & 4.5 & 0.6 & 6.2 & 0.8 & 7.1 & 0.9 \\
\hline
\end{tabular}

Note: "Percentage" is the percent of blacks in each category. "Relative to whites", is the ratio of the percentage of blacks and whites in each category.

Experience=potential experience, calculated as min[age-education-6, age-18].

Source: Authors' calculations using March CPS, 1969-1999. 
Table 3. Percentage of Whites in Selected Percentiles of the Black Wage Distribution, by Year

\begin{tabular}{|c|c|c|c|c|c|c|c|c|}
\hline $\begin{array}{l}\text { Percentiles of the } \\
\text { Black Wage Distribution }\end{array}$ & 1968 & 1975 & 1979 & 1985 & 1989 & 1995 & 2001 & $\begin{array}{l}\text { Average for all years } \\
\qquad(1968-2001)\end{array}$ \\
\hline 10th & 3.3 & 4.2 & 4.8 & 5.1 & 5.3 & 5.9 & 6.6 & 5.1 \\
\hline 25 th & 7.1 & 9.9 & 11.1 & 12.2 & 13.6 & 14.7 & 16.7 & 12.3 \\
\hline 50th & 16.8 & 24.9 & 29.3 & 27.3 & 29.7 & 32.8 & 35.8 & 28.4 \\
\hline 75th & 36.8 & 49.3 & 55.5 & 52.0 & 56.4 & 59.0 & 64.0 & 53.3 \\
\hline 90th & 62.5 & 71.1 & 75.5 & 72.7 & 76.9 & 80.1 & 81.1 & 75.2 \\
\hline
\end{tabular}

Source: Authors' calculations using March CPS 1969-2002. 


\section{TABLE 4}

\section{Estimated Contribution of Factors to Average Annual Percentage Point Trends in Black-White Weekly Earnings Differentials, 1968-2001}

Panel A. All Levels of Experience

\begin{tabular}{|c|c|c|c|}
\hline & $1968-1979$ & 1979-1989 & 1989-2001 \\
\hline \multirow[t]{2}{*}{ Overall Trend } & $1.23(0.14)$ & $-0.24(0.26)$ & $0.60(0.28)$ \\
\hline & \multicolumn{3}{|c|}{ Due to Human Capital } \\
\hline Total & $0.38(0.04)$ & $0.04(0.07)$ & $0.18(0.08)$ \\
\hline Quantities & $0.42(0.04)$ & $0.17(0.07)$ & $0.17(0.07)$ \\
\hline Prices & $-0.04(0.03)$ & $-0.13(0.06)$ & $0.01(0.07)$ \\
\hline \multirow[t]{2}{*}{ Trend Net of Human Capital } & 0.85 & -0.28 & 0.43 \\
\hline & \multicolumn{3}{|c|}{ Due to Employment Structure } \\
\hline Total & $0.56(0.05)$ & $-0.10(0.10)$ & $0.05(0.11)$ \\
\hline Quantities & $0.25(0.04)$ & $0.05(0.06)$ & $0.19(0.07)$ \\
\hline Prices & $0.31(0.04)$ & $-0.15(0.07)$ & $-0.14(0.08)$ \\
\hline \multirow[t]{2}{*}{ Trend Net of Employment Structure } & 0.29 & -0.18 & 0.38 \\
\hline & \multicolumn{3}{|c|}{ Due to Changes in Unobservables } \\
\hline Total & $0.28(0.12)$ & $-0.18(.23)$ & $0.37(0.24)$ \\
\hline Quantities & $0.55(0.12)$ & $-0.20(0.21)$ & $0.44(0.23)$ \\
\hline \multirow[t]{2}{*}{ Prices } & $-0.27(0.05)$ & $0.02(0.09)$ & $-0.07(0.10)$ \\
\hline & \multicolumn{3}{|c|}{ Summary Accounting of Contributions } \\
\hline Percent Due to Measured Variables & 77 & 25 & 38 \\
\hline Percent Due to Unmeasured Factors & 23 & 75 & 62 \\
\hline Sum, Race-specific Factors & 1.23 & 0.01 & 0.81 \\
\hline Sum, Wage Structure & 0.02 & -0.25 & -0.20 \\
\hline
\end{tabular}


Panel B. Less Than Ten Years of Experience

\begin{tabular}{|c|c|c|c|}
\hline & 1968-1979 & 1979-1989 & 1989-2001 \\
\hline \multirow[t]{2}{*}{ Overall Trend } & $1.33(0.25)$ & $-0.61(0.46)$ & $1.19(0.48)$ \\
\hline & \multicolumn{3}{|c|}{ Due to Human Capital } \\
\hline Total & $.0 .59(0.09)$ & $0.12(0.17)$ & $-0.01(0.18)$ \\
\hline Quantities & $0.57(0.08)$ & $0.26(0.15)$ & $0.00(0.16)$ \\
\hline Prices & $0.02(0.03)$ & $-0.14(0.06)$ & $-0.01(0.07)$ \\
\hline \multirow[t]{2}{*}{ Trend Net of Human Capital } & 0.74 & -0.73 & 1.18 \\
\hline & \multicolumn{3}{|c|}{ Due to Employment Structure } \\
\hline Total & $0.50(0.08)$ & $-0.34(0.14)$ & $0.34(0.15)$ \\
\hline Quantities & $0.14(0.06)$ & $-0.19(0.12)$ & $0.34(0.12)$ \\
\hline Prices & $0.36(0.05)$ & $-0.15(0.09)$ & $0.00(0.11)$ \\
\hline \multirow[t]{2}{*}{ Trend Net of Employment Structure } & 0.24 & -0.38 & 0.84 \\
\hline & \multicolumn{3}{|c|}{ Due to Changes in Unobservables } \\
\hline Total & $0.24(0.22)$ & $-0.38(0.40)$ & $0.84(0.42)$ \\
\hline Quantities & $0.29(0.22)$ & $-0.44(0.41)$ & $0.87(0.43)$ \\
\hline \multirow[t]{2}{*}{ Prices } & $-0.05(0.06)$ & $0.06(0.12)$ & $-0.03(0.12)$ \\
\hline & \multicolumn{3}{|c|}{ Summary Accounting of Contributions } \\
\hline Percent Due to Measured Variables & 82 & 42 & 29 \\
\hline Percent Due to Unmeasured Factors & 18 & 58 & 71 \\
\hline Sum, Race-specific Factors & 1.04 & -0.42 & 1.21 \\
\hline Sum, Wage Structure & 0.29 & -0.24 & -0.02 \\
\hline
\end{tabular}

Source: Authors' calculations using March CPS, 1969-2002. Note that the overall trend and all succeeding analysis control for potential experience, region of residence, whether a public sector worker, and whether self-employed. Standard errors are in parentheses. Decompositions may not sum to total due to rounding errors. 